\title{
Effect of feed selenium supplementation on milk selenium distribution and mozzarella quality
}

\author{
H. Y. Liu, ${ }^{*}$ W. Z. Zhu, ${ }^{*}$ B. Y. Lu,† Z. H. Wei, ${ }^{*}$ and D. X. Ren* ${ }^{* 1}$ \\ *Institute of Dairy Science, College of Animal Science, Zhejiang University, Hangzhou 310058, China \\ †Key Laboratory for Agro-Food Risk Assessment of Ministry of Agriculture, College of Biosystems Engineering and Food Science, \\ Zhejiang University, Hangzhou 310058, China
}

\section{ABSTRACT}

In the present study, the effect of feed Se supplementation on the Se content of raw milk and mozzarella cheese as well as the effect on cheese quality and functionality were determined. The Se milk was produced by supplying dairy cow feed with Se yeast $(0.3 \mathrm{mg}$ of $\mathrm{Se} / \mathrm{kg}$ of dry matter), resulting in a Se concentration in milk of $35.81 \mu \mathrm{g} / \mathrm{L}$. The fat, casein, and whey protein of Se milk were separated by ultracentrifugation, and the Se content was determined by atomic absorption spectroscopy. The Se distribution in different milk fractions of fat, casein, and whey protein were 9.82, 45.56 , and $44.62 \%$, respectively. The Se mozzarella cheese was made by Se milk, and the composition and texture of Se cheese did not significantly differ from that of the control. However, the functional properties (meltability, flowability, and stretchability) of the Se cheese were better after $8 \mathrm{wk}$ of storage. Moreover, the $\mathrm{pH}$ and water activity were lower in Se cheese, which decreased the total plate count. The Se content in mozzarella cheese was 4 fold higher than that in milk, and Se was found in the whey, hot water, and brine collected during cheesemaking. Organic and inorganic Se was found in the Se cheese after 8 wk of storage, and most Se peptides detected after storage were Se-Met and Se-Cys. The results of this study show that feed Se supplementation can improve the Se content of milk and cheese without affecting mozzarella cheese quality. Key words: dairy cattle, selenium supplementation, selenium distribution, Mozzarella

\section{INTRODUCTION}

Selenium is an important trace element, and Se deficiency has been associated with negative effects on hu-

Received April 7, 2015.

Accepted August 10, 2015.

${ }^{1}$ Corresponding author: dxren@zju.edu.cn man and animal health (Hatfield et al., 2014; Alfthan et al., 2015). The adult human recommended dietary allowance for Se is approximately $55 \mu \mathrm{g} / \mathrm{d}$, and the highest tolerable intake level has been set at $400 \mu \mathrm{g} / \mathrm{d}$. Interest in the administration of Se supplements has increased in recent years because of its bioactivity, including its role as an antioxidant against free radicals, its cancer-preventive properties, and its inhibition of glutathione peroxidase and other reductases (Albanes et al., 2014; Shaheen et al., 2015; Speckmann and Grune, 2015).

The population in many places around the world, such as those of China, Russia, and New Zealand, is deficient in Se (Rayman, 2000). The concentration of Se in plants and animals varies widely and depends on the Se content and characteristics of the soil. Therefore, methods to increase Se intake by preparing Se-enriched foods is a current subject of interest. Many studies have attempted to enrich different food products with Se, such as yeast, plants (rice, garlic, green onions, sesame, and broccoli; Pophaly et al., 2014; Yasin et al., 2015), and animal products (meat, milk, and egg; Calamari et al., 2010; Lin, 2014). Food can be supplemented with Se in 2 forms: inorganic forms, such as selenite and selenate, or organic forms, such as Se yeast and Se grain. A meta-analysis of the effect of oral Se supplementation on milk Se concentration in cattle has shown that cows supplemented with Se yeast produced milk with higher Se concentrations than those supplemented with inorganic forms of Se (Ceballos et al., 2009). The inorganic and organic Se forms in dietary supplements are metabolized differently in animals. Organic Se, such as Se-Met, is actively transported through and absorbed in the intestine and nonspecifically incorporated into body proteins in place of Met during protein synthesis, providing a means of reversible Se storage in organs and tissues (Schrauzer, 2003). In contrast, inorganic Se is absorbed via passive diffusion, and little is retained in tissue reserves. Consequently, a large proportion of inorganic Se is excreted in the feces and urine. Recently, Se yeast has been authorized for use within the Euro- 
pean Union as a feed additive (European Commission, 2006).

Milk and fermented milk are vital components of human nutrition and usually present in traditional meals. Milk is regularly consumed in moderate amounts and affordable. In this regard, Se-enriched milk and its fermentation products are interesting approaches to increase the human intake of organic compounds, such as Se. Several studies have been undertaken to produce Se-enriched fermented milk product by using microorganisms that biotransform inorganic Se into organic its forms, such as Se-Cys and Se-methylselenocysteine (Alzate et al., 2008; Alzate et al., 2010). Other studies have attempted to producing Se-enriched milk and fermented milk products by feed Se supplement (Moschini et al., 2010; Deng et al., 2015).

Although some studies have intended to produce Seenriched cheese (Gulbas and Saldamli, 2005; Pechova et al., 2008; Moschini et al., 2010), the effect of this enrichment on the mozzarella cheese quality and the Se content and distribution during cheesemaking and storage remains unclear. Furthermore, whether or not Se-fortified milk or dairy products produced by animals fed Se can be used in populations traditionally deficient is still in need of further study. Therefore, our study examined the Se content and distribution in milk and mozzarella cheese in response to feed Se supply and effect of Se milk on mozzarella cheese quality.

\section{MATERIALS AND METHODS}

\section{Milk Sampling}

The milk samples used in our study were obtained from a local dairy farm (Qiaosi dairy farm, Hangzhou, Zhejiang Province, China). Two groups of 16 multiparous Holstein cows in mid lactation were selected: 1 group of cows received the basal diet containing a supply of organic Se $(0.3 \mathrm{mg}$ of Se/kg of DM, Novus, St. Charles, MO) according to our previous research (Y. $\mathrm{Li}$ and J. X. Liu, Institute of Dairy Science, College of Animal Science, Zhejiang University, Hangzhou, China; unpublished data), and the other group without feed Se supplement was used as control. Ingredients and chemical compositions of diets are shown in Table 1. Diets were formulated according to nutrient requirements for lactation Holstein cows weighing $600 \mathrm{~kg}$ and producing $30 \mathrm{~kg} / \mathrm{d}$ of milk.

Milk samples from 2 groups were collected during mid lactation after a 2-mo experiment, and the milk components were analyzed by infrared spectroscopy using a Milko Scan FT 120 (Foss Electric, Hillerød, Denmark). The fat, casein, and whey in the milk were separated by ultracentrifugation $(200,000 \times g)$ for 60 min at $4^{\circ} \mathrm{C}$. The samples were frozen at $-20^{\circ} \mathrm{C}$ until analysis.

\section{Cheesemaking}

The milk used for cheesemaking was sampled from the same place and at the same time from cows with or without feed Se supply. The raw milk (30 L) was standardized to a protein-to-fat ratio of 3.1:3.5 by partial skimming, and the milk was pasteurized at $63^{\circ} \mathrm{C}$ for 30 min, followed by cooling to $35^{\circ} \mathrm{C}$. Mozzarella cheese was made as described in a previous study with some modifications (Sheehan and Guinee, 2004). The milk was inoculated with a starter culture TCC-3 (Chr. Hansen, Horsholm, Denmark). When the $\mathrm{pH}$ of the milk had decreased by $0.1 \mathrm{pH}$ units, chymosin stamix 1150 (Chr. Hansen) was added. After $30 \mathrm{~min}$, the curd was cut with 1-cm knives and allowed to heal for $15 \mathrm{~min}$. The

Table 1. Ingredients and composition (\% of DM, unless otherwise specified) of basal diets used in the experiment $(n=8)$

\begin{tabular}{lc}
\hline Item & Content \\
\hline Ingredient & \\
Corn silage & 17.3 \\
Chinese ryegrass $^{1}$ & 7.0 \\
Corn stover (pelletized) $^{1}$ & 15.0 \\
Ground corn & 14.8 \\
Steam-flaked corn & 7.4 \\
Barley & 4.9 \\
Soybean meal & 12.3 \\
Cottonseed meal & 4.9 \\
Beet pulp & 8.5 \\
Beer refusal & 2.8 \\
Calcium carbonate & 0.2 \\
Premix & 4.9 \\
Chemical composition & \\
DM (\%) & $50.5 \pm 1.24$ \\
OM & $92.5 \pm 0.48$ \\
CP & $14.9 \pm 0.43$ \\
NDF & $41.5 \pm 2.40$ \\
ADF & $24.6 \pm 1.50$ \\
NFC & $34.6 \pm 2.25$ \\
Ca & 0.68 \\
P & 0.46 \\
NE ${ }_{\mathrm{L}}^{4}$ (Mcal/kg of DM) & 1.57 \\
Se (mg/kg of DM) & 0.09 \\
\hline
\end{tabular}

${ }^{1}$ Compositions (\% of DM) are as follows $(\mathrm{n}=5)$ : Chinese ryegrass hay: $\mathrm{OM}=92.3, \mathrm{CP}=7.72, \mathrm{NDF}=67.5, \mathrm{ADF}=42.6$, and $\mathrm{NFC}=16.5$; corn stover (pelletized): $\mathrm{OM}=90.0, \mathrm{CP}=6.0, \mathrm{NDF}=56.8, \mathrm{ADF}=$ 26.7, and $\mathrm{NFC}=28.8$.

${ }^{2}$ Formulated to provide (per $\mathrm{kg}$ of $\mathrm{DM}$ ): $10 \mathrm{~g}$ of $\mathrm{CP}, 150 \mathrm{~g}$ of ether extract, $60 \mathrm{~g}$ of crude fiber, $70 \mathrm{~g}$ of Ca, $13 \mathrm{~g}$ of P, $100 \mathrm{~g}$ of salt, $30 \mathrm{~g}$ of $\mathrm{Mg}, 15 \mathrm{~g}$ of K, $10 \mathrm{~g}$ of Met, $260 \mathrm{mg}$ of $\mathrm{Cu}, 260 \mathrm{mg}$ of Fe, $1,375 \mathrm{mg}$ of $\mathrm{Zn}, 500 \mathrm{mg}$ of $\mathrm{Mn}, 112,000 \mathrm{IU}$ of vitamin A, 29,500 IU of vitamin $\mathrm{D}_{3}$, and $700 \mathrm{IU}$ of vitamin $\mathrm{E}$.

${ }^{3} \mathrm{NFC}=100-\% \mathrm{NDF}-\% \mathrm{CP}-\%$ ether extract $-\%$ ash.

${ }^{4}$ Calculated based on China Ministry of Agriculture (2004). 
temperature was increased to $42^{\circ} \mathrm{C}$ at a rate of $0.2^{\circ} \mathrm{C} /$ min, and the curd was cooked for $30 \mathrm{~min}$. After the whey was removed, the curd was trenched, cut into slabs, turned, and stacked until the $\mathrm{pH}$ decreased to approximately 5.2 to 5.3 . The curds were then milled and dry salted $(2 \%$, wt/wt of curd) before being mechanically heated, stretched under hot water $\left(10 \mathrm{~L}, 80^{\circ} \mathrm{C}\right)$ until the central temperature of curd rose to $66^{\circ} \mathrm{C}$, and then molded. The curds were formed into 1-kg loaves, immersed in brine $\left(10 \mathrm{~L}, 4^{\circ} \mathrm{C}\right)$ overnight, and stored in vacuum-sealed barrier bags at $4^{\circ} \mathrm{C}$ until analysis. The whey, hot water, and brine of Se cheese were collected and frozen until the Se content was analyzed. The control cheese was manufactured and analyzed as described previously using milk from cows without feed Se supplemented, with whey, hot water, and brine also collected for Se determination.

\section{Compositional and Water Activity Analysis of Cheese}

The fat content of the cheese was determined with the Gerber method, the moisture content was determined with the oven-drying method (IDF, 1958), and the protein content was determined with the macro-Kjeldahl method (IDF, 1993). The $\mathrm{pH}$ was measured by inserting a calibrated Unicam glass $\mathrm{Ag} / \mathrm{AgCl}$ combination $\mathrm{pH}$ electrode attached to a $\mathrm{pH}$ meter (Seven Easy*Plu, Mettler-Toledo, Columbus, $\mathrm{OH}$ ) directly into the cheese at 6 randomly chosen locations. The water activity $\left(\mathbf{a}_{\mathrm{w}}\right)$ was measured using a HygroPalm AW1 (Rotronic, Bassersdorf, Switzerland). All analyses were performed in triplicate. The moisture content of nonfat substances and the fat content of DM were calculated based on the results of the individual constituents. Samples content of Ca were analyzed using standard International Dairy Federation methods (IDF, 1992). The viable bacterial count was determined following standard microbiological procedures for dairy products (Robert, 1992). Samples $(10 \mathrm{~g})$ of cheese were homogenized in $90 \mathrm{~mL}$ of sterile sodium citrate for $2 \mathrm{~min}$ using a stomacher. The samples were diluted in sterile PBS and plated onto plate count agar. The total bacterial counts were determined after $48 \mathrm{~h}$ of incubation at $30^{\circ} \mathrm{C}$.

\section{Texture Profile Analysis}

The textural properties were measured using a texture analyzer (TA-XTPlus, Stable Micro Systems, Surrey, UK) fitted with a P/N 0.5 probe (10-mm diameter) moving at a speed of $1 \mathrm{~mm} / \mathrm{s}$ for a distance of 8 mm using a cycle or normal programs. The hardness, springiness, and adhesiveness of cheese were calculated as described previously (Ayad et al., 2004). The analyses were conducted in triplicate.

\section{Cheese Functionality after Heating}

The cheese functionality, including the meltability, stretchability, and flowability, was tested after heating the cheeses. The flowability was measured with a modified Schreiber method, defined as the percentage increase in the diameter of a disc of cheese (Mounsey and O'Riordan, 1999). The meltability of the cheeses was determined using the Arnott test (Park et al., 1984), which measures the change in the sample height after heating at $100^{\circ} \mathrm{C}$ for $15 \mathrm{~min}$. The stretchability of the molten cheese $\left(280^{\circ} \mathrm{C}\right.$ for $\left.4 \mathrm{~min}\right)$ was measured using a fork test (Wadhwani et al., 2011). One minute after baking, a stainless steel, 4-pronged fork was inserted into the cheese and then lifted vertically, and the distance for which the cheese could be lifted before breaking was measured. All tests were performed in triplicate.

\section{Se Content and Distribution Determination}

Total Se Determination. The total Se contents of the feed, milk and cheese samples as well as of different parts of milk (casein, whey, and fat) and water from cheese processing (whey, hot water, and brine) were determined. The total Se content was determined after a digestion as previously described with some revision (Heard et al., 2007). Samples were mineralized with 2 $\mathrm{mL}$ of $(3: 1) \mathrm{HNO}_{3} / \mathrm{H}_{2} \mathrm{O}_{2}$ in a microwave oven. The Se (VI, selenium isotope ${ }^{82} \mathrm{Se}$ ) in the digested sample was directly reduced to Se (IV, selenium isotope ${ }^{78} \mathrm{Se}$ ) by adding $1.9 \mathrm{~mL}$ of $8 \mathrm{M} \mathrm{HCl}$ and microwaving the sample for 6 min at $650 \mathrm{~W}$. The samples were then diluted with $4 \mathrm{M} \mathrm{HCl}$ to a final volume of $10 \mathrm{~mL}$. The samples were measured by Atomic Fluorescence Spectroscopy ICE 3500 (Thermo Fisher Scientific, Waltham MA) using external calibration.

Determination of Se Species by HPLC-ICP$\boldsymbol{M S}$. The Se species in the milk and cheese were quantified by HPLC-inductively coupled plasma (ICP)MS as described previously (Alzate et al., 2010). The milk and cheese samples were initially incubated for $5 \mathrm{~h}$ with 1,4-dithiothreitol (DTT) and iodoacetamide to reduce and alkylate the Se-Cys. The solutions were then spiked with Se-Met and incubated with protease and lipase for $24 \mathrm{~h}$ at $37^{\circ} \mathrm{C}$ and $\mathrm{pH} 7.5$. Subsequently, the sample was centrifuged $(10,000 \mathrm{rpm}$ for $20 \mathrm{~min}$ at $4^{\circ} \mathrm{C}$ ), and the supernatant was collected and analyzed by RP-HPLC (Xevo TQ, Waters, Milford, MA) using an ICP-MS equipped with a collision cell. Both Se-Met 
Table 2. The composition of cheese (means $\pm \mathrm{SD}$ ) made from milk with or without Se supply (\%, unless otherwise noted)

\begin{tabular}{lcc}
\hline Item & Control & Se cheese \\
\hline Protein & $23.4 \pm 1.62$ & $22.7 \pm 1.05$ \\
Fat & $26.5 \pm 0.72$ & $25.7 \pm 0.67$ \\
Moisture & $44.8 \pm 0.87$ & $46.4 \pm 1.23$ \\
Ash & $3.48 \pm 0.26$ & $3.54 \pm 0.34$ \\
FDM $^{1}$ & $49.5 \pm 0.76$ & $49.5 \pm 1.06$ \\
MNFS $^{2}$ & $62.4 \pm 1.17$ & $63.9 \pm 0.63$ \\
Ca $(\mathrm{mg} / \mathrm{L})$ & $158 \pm 1.71$ & $162 \pm 1.45$ \\
\hline
\end{tabular}

${ }^{1} \mathrm{FDM}=$ fat-in-dry matter.

${ }^{2} \mathrm{MNFS}=$ moisture-in-nonfat-substances.

and Se-Cys standards were purchased from Sigma Aldrich (St. Louis, MO). The Se species were identified and quantified by comparing their retention times with those of the Se standards and using the standard addition method.

\section{Statistical Analysis}

At least 3 replicates were undertaken for each index. An independent $t$-test and a one-way ANOVA were applied to the experimental data $(\mathrm{n}>3)$ using the general linear model and the SPSS statistical software package (17.0; SPSS Inc., Chicago, IL). All differences were considered statistically significant at $P<0.05$. Tukey pairwise comparisons were performed for significant differences.

\section{RESULTS}

\section{Cheese Composition}

Data on the gross composition of Se and control cheeses are summarized in Table 2. The protein, fat, moisture, and ash contents did not significantly differ between the Se and control cheese. Therefore, the fat content of DM and moisture content of nonfat substances were also similar between the 2 cheeses. Besides, the Ca content of the Se cheese was $162 \mathrm{mg} / \mathrm{L}$, similar to that of the control cheese $(158 \mathrm{mg} / \mathrm{L}, P>$
0.05). Similar results were also found in goat cheese made from milk obtained from goats with feed SeI and $\mathrm{SeO}$ supply. The results of our study showed that a Se supply in feed does not significantly affect mozzarella cheese composition.

\section{The $\mathrm{pH}, \mathrm{a}_{\mathrm{w}}$, and Total Plate Count}

The $\mathrm{pH}, \mathrm{a}_{\mathrm{w}}$, and total plate count (TPC) of the 2 cheeses during the 2-mo storage period are shown in Table 3 . The $\mathrm{pH}$ values of the 2 cheeses were similar at the beginning, but the $\mathrm{pH}$ of the control rose from 5.05 to 5.14 during storage, which was similar to findings from other studies of mozzarella cheese (Sheehan and Guinee, 2004). However, the $\mathrm{pH}$ of the Se cheese dropped from 5.05 to 4.98 during the 2-mo storage period. After 2 mo of storage, the $\mathrm{pH}$ of Se cheese was significantly lower than that of the control $(P<0.05)$.

During storage, $a_{\mathrm{w}}$ of both cheeses increased during the first month and then decreased during the second month. Similar results were also found in other cheeses during storage, such as Queso Fresco (Guo et al., 2011). The $a_{w}$ during storage did not significantly differ between the 2 types of cheese, although the $\mathrm{a}_{\mathrm{w}}$ of the Se cheese remained lower throughout storage.

The TPC of the 2 cheeses also differed during storage. The TPC of the 2 cheeses was similar at the beginning but rapidly increased in the control compared with the Se cheese during storage $(P<0.05)$. After 2 mo of storage, the TPC of the control was $7.97 \log _{10} \mathrm{cfu} / \mathrm{g}$, whereas that of the Se cheese was $3.01 \log _{10} \mathrm{cfu} / \mathrm{g}(P$ $<0.05)$.

\section{Texture}

The textures of 2 cheeses during the 2 mo of storage are shown in Table 4 . The 2 mozzarella cheeses softened during 2 mo of storage, which agrees with previous studies of reduced-fat mozzarella cheese (Guinee et al., 2002). The textures of the 2 cheeses, such as the springiness and cohesiveness, did not significantly differ. The

Table 3. The water activity $\left(\mathrm{a}_{\mathrm{w}}\right), \mathrm{pH}$, and total plate count (TPC) of the 2 cheeses during the different storage times, expressed as means $\pm \mathrm{SD}$

\begin{tabular}{llccc}
\hline Sample & Storage (wk) & $\mathrm{a}_{\mathrm{w}}$ & $\mathrm{pH}$ & $\begin{array}{c}\text { TPC } \\
\left(\log _{10} c f u / g\right)\end{array}$ \\
\hline Control & 0 & $0.969 \pm 0.003^{\mathrm{ab}}$ & $5.05 \pm 0.03^{\mathrm{b}}$ & $2.37 \pm 0.34^{\mathrm{bc}}$ \\
& 4 & $0.975 \pm 0.006^{\mathrm{a}}$ & $5.10 \pm 0.02^{\mathrm{ab}}$ & $4.87 \pm 0.41^{\mathrm{b}}$ \\
Se & 8 & $0.953 \pm 0.011^{\mathrm{bc}}$ & $5.14 \pm 0.03^{\mathrm{a}}$ & $7.97 \pm 0.45^{\mathrm{a}}$ \\
& 0 & $0.961 \pm 0.006^{\mathrm{b}}$ & $5.05 \pm 0.04^{\mathrm{b}}$ & $1.99 \pm 0.17^{\mathrm{c}}$ \\
& 4 & $0.965 \pm 0.009^{\mathrm{ab}}$ & $5.01 \pm 0.04^{\mathrm{bc}}$ & $2.59 \pm 0.11^{\mathrm{bc}}$ \\
& 8 & $0.945 \pm 0.003^{\mathrm{c}}$ & $4.98 \pm 0.02^{\mathrm{c}}$ & $3.01 \pm 0.53^{\mathrm{bc}}$ \\
\hline
\end{tabular}

${ }^{a-c}$ Means within a column with the same superscript letter were not significantly different $(P<0.05)$. 
Table 4. Age-related changes (means \pm SD) in the texture of cheeses with or without Se supply

\begin{tabular}{llccc}
\hline Sample & Storage (wk) & Hardness $(\mathrm{g})$ & Springiness $(\mathrm{mm})$ & Cohesiveness (ratio) \\
\hline Control & 0 & $304 \pm 67^{\mathrm{a}}$ & $0.95 \pm 0.11$ & $0.51 \pm 0.09$ \\
& 4 & $188 \pm 19^{\mathrm{b}}$ & $0.88 \pm 0.02$ & $0.59 \pm 0.04$ \\
Se & 8 & $160 \pm 21^{\mathrm{bc}}$ & $0.90 \pm 0.04$ & $0.50 \pm 0.07$ \\
& 0 & $275 \pm 52^{\mathrm{a}}$ & $0.96 \pm 0.03$ & $0.53 \pm 0.03$ \\
& 4 & $136 \pm 11^{\mathrm{bc}}$ & $0.93 \pm 0.12$ & $0.61 \pm 0.15$ \\
& 8 & $83.0 \pm 6.5^{\mathrm{c}}$ & $0.93 \pm 0.03$ & $0.61 \pm 0.02$ \\
\hline
\end{tabular}

${ }^{a-c}$ Means within a column with the same superscript letter were not significantly different $(P<0.05)$.

control cheese was harder than the Se cheese, although this difference was not remarkable. The hardness decreased during storage due to the increase in primary proteolysis; the hardness inversely correlated with proteolysis (Guinee et al., 2002). The control cheese was harder than the Se cheese, although this difference was not remarkable. This difference may be due to the low moisture content of the Se cheese and increased lactic acid production during storage.

\section{Functionality of Heated Cheese}

The changes in the functional characteristics of the 2 cheeses that occurred during the 8 wk of storage are shown in Figure 1. The functional characteristics of 2 cheeses did not significantly differ at first, however, all of the characteristics was significantly improved after 8 wk of storage. The meltability and flowability of the Se cheese was significantly higher than that of the control after $8 \mathrm{wk}$ of storage. The stretchability of the Se cheese was also higher after storage, showing a trend similar to those of the flowability and meltability, but this difference was not significant $(P>0.05)$.

\section{Selenium Content and Distribution in Milk and Cheese}

Se Content and Distribution in Milk. The Se content of raw milk after 2 mo of feed supplementation $(0.3 \mathrm{mg}$ of $\mathrm{Se} / \mathrm{kg}$ of $\mathrm{DM})$ was $35.81 \mu \mathrm{g} / \mathrm{L}$, significantly higher than the control milk $(5.53 \mu \mathrm{g} / \mathrm{L}$, Table 5$)$. The Se distribution in whey milk, casein micelles, and the fat phase was determined from 8 milk samples. The Se content in the Se milk decreased in the following order: casein $>$ whey $>$ fat. The highest selenium levels were found in casein (45.56\%), whereas the Se content was lowest in the fat $(9.82 \%)$. Different from Se milk, the Se content in whey $(46.92 \%)$ was higher than casein in the control group (42.44\%).

Se Content and Distribution in Cheesemaking. The Se content of cheese and water collected during cheesemaking is shown in Table 5. After processing the Se content in cheese increased by more than 4 fold, from $35.81 \mu \mathrm{g} / \mathrm{L}$ in milk to $145.77 \mu \mathrm{g} / \mathrm{kg}$ in mozzarella cheese. Similarly, the Se content in control group increased from $5.53 \mu \mathrm{g} / \mathrm{L}$ in milk to $20.41 \mu \mathrm{g} / \mathrm{kg}$ in mozzarella cheese.

The remaining Se in milk was lost to the whey, hot water, brine, and other processes used to make cheese. The Se content in whey, hot water, and brine collected during the mozzarella cheesemaking was measured by atomic fluorescence spectroscopy as 15.26, 1.43, and $0.51 \mu \mathrm{g} / \mathrm{L}$, respectively (Table 5 ). The remaining Se in the control group was only found in whey, in hot water and brine was too low to detect. The Se content of hot water and brine may depend on the amount of water used, the temperature of the hot water, and the salt content of the brine.

Se Protein and Peptides in Milk and Cheese. The Se components in milk and cheese are shown in Table 6 and Figure 2. The Se components include inorganic $\mathrm{Se}\left(\mathrm{SeO}_{4}{ }^{2-}\right.$ and $\left.\mathrm{SeO}_{3}{ }^{2-}\right)$ and organic $\mathrm{Se}(\mathrm{Se}-\mathrm{Met}$, Se-Cys, and others), which were found in both milk and cheese samples. The concentrations of Se-Met and Se-Cys in milk were 146 and $65 \mathrm{ng} / \mathrm{g}$, respectively. The identification of Se species in mozzarella cheese made from Se milk after 2 mo of supplementation is shown in Table 6. The concentrations of the Se-Met, Se-Cys, and other Se compounds in cheese were 215, 123, and 105 $\mathrm{ng} / \mathrm{g}$, respectively.

\section{DISCUSSION}

\section{Feed Se Supply Influence on Cheese Quality}

$p H, a_{w}$, and $T P C$. In the current study, no significant difference of $\mathrm{pH}, \mathrm{a}_{\mathrm{w}}$, and TPC was found at $0 \mathrm{wk}$; however, after 2 mo of storage, a significant difference was found. The $\mathrm{pH}$ at $8 \mathrm{wk}$ (5.14) was higher than at 0 wk $(5.05)$ in control $(P<0.05)$. A similar result was also found in low-fat mozzarella cheese. The increased $\mathrm{pH}$ during storage may be due to a loss of lactic acid, soluble $\mathrm{Ca}$, and phosphate in the stretch water and to the resolubilization of micellar calcium phosphate upon cooling the cheese after plasticization (Guinee et al., 2002). Compared with control, different trends 

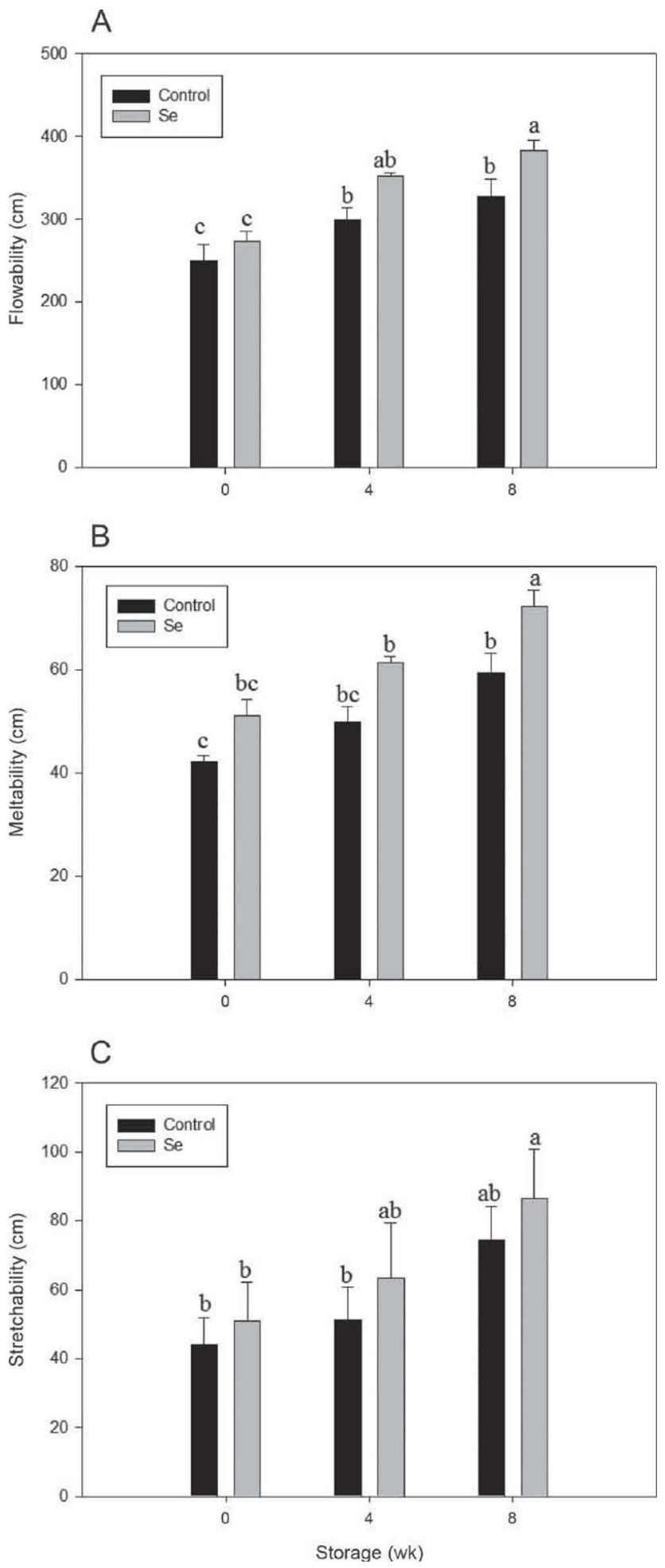

Figure 1. Age-related changes during the whole storage time in flowability, as measured by the modified Schreiber method (A), meltability tested by Arnott test (B), and stretchability (C) of Mozzarella cheeses made with (Se) or without Se (control) in feed. Details of the preparation and compositions are given in the text. Values presented are the means of 3 replicate trials. Error bars represent standard deviations; bars with the same letters $(\mathrm{a}, \mathrm{b}, \mathrm{c})$ are not significantly different $(P<0.05)$.

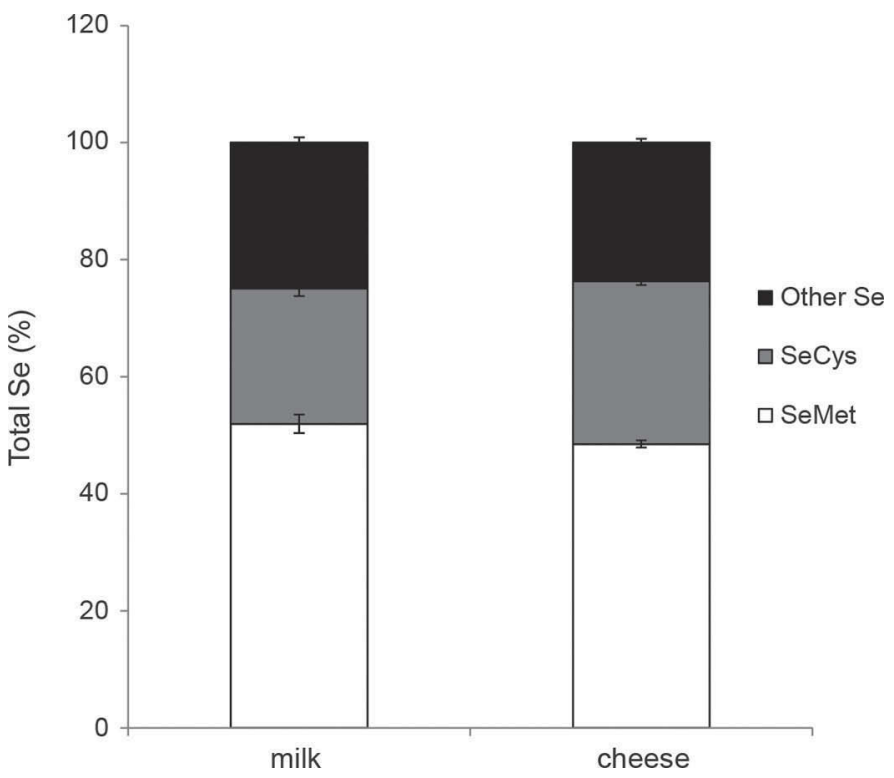

Figure 2. Proportion of Se in the form of Se-Met (white bars), SeCys (gray bars), and other Se forms (black bars) in milk and cheese of dairy cows that were supplemented with Se via the feed at $0.3 \mathrm{mg}$ of $\mathrm{Se} / \mathrm{kg}$ of DM. Values are least squares means (Se of each fraction in percentage of total Se) and SEM.

were found in Se cheese, as the $\mathrm{pH}$ was dropped during the storage. The decreased $\mathrm{pH}$ may be related to the count and activity of lactic acid bacteria. The $\mathrm{a}_{\mathrm{w}}$ of both cheeses decreased during the storage. The $\mathrm{a}_{\mathrm{w}}$ reflects the mobility of protons in the water, which is entrapped in a more open protein matrix. This water is likely to be more mobile in the control cheese due to its higher $\mathrm{pH}$. The $\mathrm{a}_{\mathrm{w}}$ of cheese depends on its moisture content and the concentration of low-molecular mass solutes; the lower $\mathrm{a}_{\mathrm{w}}$ of Se cheese may be due to the concentration of low-molecular mass solutes produced during the storage, which leads to the dehydration and inactivation of bacterial cells, such as the growth of spoilage organism shown below. Another interesting point of our study is that the TPC in Se cheese (3.01

Table 5. Selenium concentrations $(\mu \mathrm{g} / \mathrm{L})$ and distribution in different components of milk and cheese, expressed as mean \pm SD

\begin{tabular}{lcc}
\hline Component & Se & \multicolumn{1}{c}{ Control } \\
\hline Milk & $35.8 \pm 3.89$ & $5.5 \pm 1.22$ \\
Total & $45.6 \pm 5.31$ & $42.4 \pm 6.57$ \\
Casein (\%) & $44.6 \pm 4.57$ & $46.9 \pm 7.33$ \\
Whey (\%) & $9.82 \pm 2.14$ & $10.7 \pm 3.08$ \\
Fat (\%) & $146 \pm 10.3$ & $20.4 \pm 2.34$ \\
Cheese & $13.3 \pm 1.56$ & $2.24 \pm 0.28$ \\
Total $(\mu \mathrm{g} / \mathrm{kg})$ & $1.43 \pm 0.21$ & $\mathrm{ND}^{1}$ \\
Whey & $0.51 \pm 0.13$ & $\mathrm{ND}$ \\
Hot water & & \\
Brine & &
\end{tabular}

${ }^{1}$ Not detected. 
Table 6. Selenium components and concentration in milk and cheese dry samples, expressed as means $\pm \mathrm{SD}$

\begin{tabular}{lcc}
\hline Item & Milk $(\mathrm{ng} / \mathrm{g})$ & Cheese $(\mathrm{ng} / \mathrm{g})$ \\
\hline Se-Met & $146 \pm 11$ & $215 \pm 15$ \\
Se-Cys & $65 \pm 8$ & $123 \pm 13$ \\
Other & $70 \pm 9$ & $105 \pm 14$ \\
\hline
\end{tabular}

$\log 10 \mathrm{cfu} / \mathrm{g})$ is lower than that in control $(7.97 \log 10$ $\mathrm{cfu} / \mathrm{g})$, the reason may be also related to the $\mathrm{pH}, \mathrm{a}_{\mathrm{w}}$, and Se in cheese.

The relationship among the $\mathrm{Se}, \mathrm{pH}$, and $\mathrm{TPC}$ in $\mathrm{Se}$ cheese is worth further study. The lower TPC in Se cheese during storage may be related to Se. A previous study found that Se-rich probiotics can guard against the pathogen Escherichia coli both in vitro and in vivo by improving the organic antioxidant performance and enhancing immunity and the internal environment of the intestinal tract of the animal model (Yang et al., 2009). It is also possible the Se in cheese promote lactic acid bacteria growth, leading to low $\mathrm{pH}$ and TPC. However, the effect of Se on lactic acid bacteria is still unclear, and more study is needed on the effect of Se on lactic acid bacteria number and activity during storage.

Cheese Functionality. In agreement with previous studies (Sheehan and Guinee, 2004), the mean meltability, flowability, and stretchability of both cheeses significantly increased during the 8-wk storage period. These changes can be attributed to the increase in casein hydration, as reflected by the increase in the nonexpressible serum and the decrease in the levels of intact casein due to microorganisms and enzymes, and other factors, such as fat coalescence and the waterbinding capacity of the casein matrix, which promote the heat-induced displacement of adjoining layers of the casein matrix upon heating (Guinee et al., 2002; Sheehan and Guinee, 2004).

As shown in Figure 1, the flowability of Se cheese was significantly higher than that of the control after 8 wk. This difference may be due to the lower $\mathrm{pH}$ of the Se cheese, which leads to higher a ratio of soluble-tocolloidal Ca for a similar total Ca content, and thereby allowing a greater displacement of contiguous layers of the casein matrix under given heat-induced stress (Sheehan and Guinee, 2004). The hydration of casein or paracasein in dilute solutions also increased at low $\mathrm{pH}$ (Guinee et al., 2002). Other factors, such as the relatively low level of protein and high levels of moisture, may also likely have contributed to the higher flowability of Se cheese. Similarly, the meltability of the Se cheese was significantly higher than that of the control. This difference could also be attributed to the $\mathrm{pH}$ and casein matrix because a lower $\mathrm{pH}$ and lactic acid content in Se cheese led to highly hydrated pro- tein matrices and fewer protein interactions. Thus, the bonds between proteins are much weaker and require less energy to break (McMahon et al., 2005). In addition, this difference may also be due to the moisture and $\mathrm{Ca}$ content and distribution in the 2 cheeses; the stretchability of the Se cheese was also higher after storage. This similarity of trends was expected because both parameters depend on the displacement of the paracasein matrix. Because the higher degree of protein cross-linking and higher levels of primary proteolysis, the degree of displacement for a given stress applied during the extension was expected to increase for the Se cheese (Sheehan and Guinee, 2004). What the role of $\mathrm{Se}$ is in cheese and how Se influences the cheese functionality through casein matrix is still unclear and needs further study.

\section{Feed Se Supply Influence Se Content and Distribution}

Se Content in Milk. Many studies have reported the effect of oral Se supplementation on cow or goat milk Se concentration. Our previous study also used sodium selenite $(0.3 \mathrm{mg}$ of $\mathrm{Se} / \mathrm{kg}$ of $\mathrm{DM})$, and Se yeast $(0.1,0.3,0.5 \mathrm{mg}$ of $\mathrm{Se} / \mathrm{kg}$ of $\mathrm{DM})$ in the feed for dairy cow (Y. Li and J. X. Liu, Institute of Dairy Science, College of Animal Science, Zhejiang University, Hangzhou, China; unpublished data). Milk Se content rose to $47.9 \mu \mathrm{g} / \mathrm{L}$ in the $0.5-\mathrm{mg}$ Se group, but milk production was significantly lower compared with the 0.1- and $0.3-\mathrm{mg}$ organic Se groups; therefore, we used $0.3 \mathrm{mg}$ of Se yeast in the current study. Although we did not add Se in the control group, Se was detected in the feed $(0.09 \mathrm{mg} / \mathrm{kg}$ of DM) and control milk $(5.53 \mu \mathrm{g} / \mathrm{L})$. The Se content of milk was primarily affected by the feed Se species and dose. According to these reports, the Se concentration in raw milk was 0.07 to $1.65 \mu \mathrm{mol} / \mathrm{L}$, and American cows supplemented with Se yeast produced milk containing more Se (approximately $0.37 \mu \mathrm{mol} / \mathrm{L}$ ). A meta-analysis showed that the Se content of milk was affected by geographic factors and factors related to the study design, such as the stage of lactation, Se source, and Se dose (Ceballos et al., 2009). The translation ratio of organic Se is higher than that of sodium selenite; mechanisms distinct from those of inorganic forms are thought to metabolize seleno-AA from Se yeast, which may be preferable to enhance the Se concentration in milk.

Se Distribution in Milk and Cheese. The Se concentrations and distribution in milk and cheese was shown in Table 5. Unlike in our study, other researchers found that the whey contained the most Se $(47-53 \%)$, followed by casein (37-43\%) and fat (7.3-9.3\%; Muñiz-Naveiro et al., 2005) in Se milk, similar to the Se 
distribution in our control cheese. The reason for the difference in Se distribution in milk is still unclear, but may be due to the milk composition, Se species in the feed, geographical location, and cow breed.

Compared with milk, higher Se concentrations were found in both cheeses. Consistent with our study, other researchers found that the Se content increased from $23 \mu \mathrm{g} / \mathrm{L}$ in milk to $117 \mu \mathrm{g} / \mathrm{kg}$ in Grana Padano cheese (Moschini et al., 2010), from $250 \mathrm{ng}$ of Se/g in dry milk to $340 \mathrm{ng}$ of $\mathrm{Se} / \mathrm{g}$ in dry Caerphilly cheese (Phipps et al., 2008), and from $12.5 \mu \mathrm{g} / \mathrm{L}$ in goat milk to $70 \mu \mathrm{g} / \mathrm{kg}$ in natural goat cheese (Pechova et al., 2008). The Se in cheese should come from the casein and fat, as most of the whey is drained during the cheesemaking, other Se was lost during the stretching.

Inorganic $\mathrm{Se}\left(\mathrm{SeO}_{4}{ }^{2-}\right.$ and $\left.\mathrm{SeO}_{3}{ }^{2-}\right)$ and organic $\mathrm{Se}$ (Se-Met, Se-Cys, and others), were found in both Se milk and cheese samples after 8 wk of storage. In previous studies that used cows and goats as models, up to $312 \mathrm{ng} / \mathrm{g}$ of Se-Met and $75 \mathrm{ng} / \mathrm{g}$ of Se-Cys were found in cow milk; all results showed higher Se-Met content than Se-Cys content (Phipps et al., 2008; Petrera et al., 2009; Calamari et al., 2010). The higher Se-Met content in milk was expected because Se-Met is nonspecifically absorbed in the intestinal tract and remains intact and available for protein synthesis in place of Met; Se from Se-Met was shown to be able to incorporate into proteins, presumably as Se-Met within the Met pool (Burk et al., 2001). The conversion rate of organic Se (Se yeast) in the feed is higher than that of inorganic Se (sodium selenite and sodium selenate) because the inorganic Se is almost exclusively used to produce selenoenzymes, whereas organic Se can be used to produce both selenoenzymes and generally label all proteins containing Met.

The higher Se-Met concentration in cheese could be attributed to the higher concentration in milk. Phipps et al. (2008) reported the concentrations of Se-Met, Se-Cys, and other Se compounds in Caerphilly cheese as 153,92 , and $63 \mathrm{ng} / \mathrm{g}$, respectively. The different Se concentration in our study was primarily attributed to the Se concentration in milk and different cheese.

Se-Fortified Milk and Dairy Products Potential. Selenium is an important trace element and Se deficiency has been associated with negative effects in human and animal health. People in countries such as China and Russia have lower dietary intake of Se than recommended, causing a need for supplementation by food or drug. Therefore, Se-enriched food, including plant products, animal products, and yeast, were developed. Compared with drugs, Se-enriched food is more easily acceptable for its lower price and convenient intake. Selenium-fortified food or dairy products could be used all over the world. Selenium-fortified dairy products have several advantages compared with other foods, including higher Se content, well accepted and convenient intake, low price, and safety. However, further study of milk process on quality and flavor of Se products is still needed before marketing. Other Sefortification methods, such as adding Se yeast to milk or cheese, also need further research.

\section{CONCLUSIONS}

A supplement of Se in the feed can lead to high Se content in milk and cheese. Enriching cow milk with Se does not affect the composition and texture of fresh mozzarella cheese. Compared with the control, the functional properties of Se cheese remarkably changed during storage. After 2 mo of storage, the meltability, flowability, and stretchability of Se cheese were significantly higher than that of the control. The TPC of the Se cheese was lower than that of the control during storage, which could be due to the low $\mathrm{pH}, \mathrm{a}_{\mathrm{w}}$, and Se in the cheese. Most of the Se in milk and cheese was combined with protein or peptides, and the Se content increased by nearly 4 -fold after cheesemaking. The Se in milk and cheese primarily consisted of Se-Met and Se-Cys. The Se bioactive peptides produced during cheese ripening and their effect on cheese quality requires further research.

\section{ACKNOWLEDGMENTS}

This research was funded by the Zhejiang University Seed Foundation of Interdisciplinary Research for Young Teacher (JCZZ-2013029). The authors thank B. J. Liu (Institute of Feed Science, College of Animal Science, Zhejiang University) for the selenium analyses.

\section{REFERENCES}

Albanes, D., C. Till, E. A. Klein, P. J. Goodman, A. M. Mondul, S. J. Weinstein, P. R. Taylor, H. L. Parnes, J. M. Gaziano, X. L. Song, N. E. Fleshner, P. H. Brown, F. L. Meyskens, and I. M. Thompson. 2014. Plasma tocopherols and risk of prostate cancer in the selenium and vitamin E cancer prevention trial (SELECT). Cancer Prev. Res. (Phila.) 7:886-895.

Alfthan, G., M. Eurola, P. Ekholm, E. R. Venalainen, T. Root, K. Korkalainen, H. Hartikainen, P. Salminen, V. Hietaniemi, P. Aspila, A. Aro, and S. W. Grp. 2015. Effects of nationwide addition of selenium to fertilizers on foods, and animal and human health in Finland: From deficiency to optimal selenium status of the population. J. Trace Elem. Med. Biol. 31:142-147.

Alzate, A., A. Fernandez-Fernandez, M. C. Perez-Conde, A. M. Gutierrez, and C. Camara. 2008. Comparison of biotransformation of inorganic selenium by Lactobacillus and Saccharomyces in lactic fermentation process of yogurt and kefir. J. Agric. Food Chem. $56: 8728-8736$

Alzate, A., M. C. Perez-Conde, A. M. Gutierrez, and C. Camara. 2010. Selenium-enriched fermented milk: A suitable dairy product to improve selenium intake in humans. Int. Dairy J. 20:761-769. 
Ayad, E. H. E., S. Awad, A. El Attar, C. de Jong, and M. El-Soda. 2004. Characterisation of Egyptian Ras cheese. 2. Flavour formation. Food Chem. 86:553-561.

Burk, R. F., K. E. Hill, and A. K. Motley. 2001. Plasma selenium in specific and non-specific forms. Biofactors 14:107-114.

Calamari, L., F. Petrera, and G. Bertin. 2010. Effects of either sodium selenite or Se yeast (Sc CNCM I-3060) supplementation on selenium status and milk characteristics in dairy cows. Livest. Sci. 128:154-165.

Ceballos, A., J. Sanchez, H. Stryhn, J. B. Montgomery, H. W. Barkema, and J. J. Wichtel. 2009. Meta-analysis of the effect of oral selenium supplementation on milk selenium concentration in cattle. J. Dairy Sci. 92:324-342.

China Ministry of Agriculture. 2004. Feeding Standard of Dairy Cattle (NY/T 34 - 2004). China Agricultural Press, Beijing, China.

Deng, Y., C. X. Man, Y. Fan, Z. Wang, L. Li, H. Ren, W. J. Cheng, and Y. J. Jiang. 2015. Preparation of elemental selenium-enriched fermented milk by newly isolated Lactobacillus brevis from kefir grains. Int. Dairy J. 44:31-36.

European Commission. 2006. Commission regulation (EC)No 1750/2006 of 27 November 2006 concerning the authorisation of selenomethionine as feed additive. 28 November 2006, Official Journal of the European Union. L 330/9-11.

Guinee, T. P., E. P. Feeney, M. A. E. Auty, and P. F. Fox. 2002. Effect of $\mathrm{pH}$ and calcium concentration on some textural and functional properties of Mozzarella cheese. J. Dairy Sci. 85:1655-1669.

Gulbas, S. Y., and I. Saldamli. 2005. The effect of selenium and zinc fortification on the quality of Turkish white cheese. Int. J. Food Sci. Nutr. 56:141-146.

Guo, L., D. L. Van Hekken, P. M. Tomasula, J. Shieh, and M. H. Tunick. 2011. Effect of salt on the chemical, functional, and rheological properties of Queso Fresco during storage. Int. Dairy J. 21:352-357.

Hatfield, D. L., P. A. Tsuji, B. A. Carlson, and V. N. Gladyshev. 2014. Selenium and selenocysteine: Roles in cancer, health, and development. Trends Biochem. Sci. 39:112-120.

Heard, J. W., C. R. Stockdale, G. P. Walker, C. M. Leddin, F. R. Dunshea, G. H. McIntosh, P. M. Shields, A. McKenna, G. P. Young, and P. T. Doyle. 2007. Increasing selenium concentration in milk: Effects of amount of selenium from yeast and cereal grain supplements. J. Dairy Sci. 90:4117-4127.

IDF. 1958. Determination of dry matter in cheese and processed cheese. Standard FIL-IDF 4. International Dairy Federation, Brussels, Belgium.

IDF. 1992. Milk and dried milk. Determination of calcium content. Flame atomic absorption spectrometric method. International standard 154. International Dairy Federation, Brussels, Belgium.

IDF. 1993. Milk: Determination of nitrogen content, Part 3: Block digestion method (semi-micro rapid routine method), annex-modified procedure for milk products. Standard FIL-IDF 20B. International Dairy Federation, Brussels, Belgium.

Lin, Y. H. 2014. Effects of dietary organic and inorganic selenium on the growth, selenium concentration and meat quality of juvenile grouper Epinephelus malabaricus. Aquaculture 430:114-119.

McMahon, D. J., B. Paulson, and C. J. Oberg. 2005. Influence of calcium, $\mathrm{pH}$, and moisture on protein matrix structure and functionality in direct-acidified nonfat Mozzarella cheese. J. Dairy Sci. 88:3754-3763.
Moschini, M., M. Battaglia, G. M. Beone, G. Piva, and F. Masoero. 2010. Iodine and selenium carry over in milk and cheese in dairy cows: effect of diet supplementation and milk yield. Animal 4:147155 .

Mounsey, J. S., and E. D. O'Riordan. 1999. Empirical and dynamic rheological data correlation to characterize melt characteristics of imitation cheese. J. Food Sci. 64:701-703.

Muñiz-Naveiro, O., R. Dominguez-Gonzalez, A. Bermejo-Barrera, J. A. C. De Juan, J. M. F. Bermudez, A. G. Pereiras, A. L. Santamaria, I. M. Lede, J. V. Puente, L. F. C. Gomez, and P. BermejoBarrera. 2005. Selenium content and distribution in cow's milk supplemented with two dietary selenium sources. J. Agric. Food Chem. 53:9817-9822.

Park, J., J. R. Rosenau, and M. Peleg. 1984. Comparison of 4 procedures of cheese meltability evaluation. J. Food Sci. 49:1158-1162.

Pechova, A., B. Janstova, L. Misurova, M. Drackova, L. Vorlova, and L. Pavlata. 2008. Impact of supplementation of various selenium forms in goats on quality and composition of milk, cheese and yoghurt. Acta Vet. (Brno) 77:407-414.

Petrera, F. L. Calamari, and G. Bertin. 2009. Effect of either sodium selenite or Se-yeast supplementation on selenium status and milk characteristics in dairy goats. Small Rumin. Res. 82:130-138.

Phipps, R. H., A. S. Grandison, A. K. Jones, D. I. Juniper, E. Ramos-Morales, and G. Bertin. 2008. Selenium supplementation of lactating dairy cows: effects on milk production and total selenium content and speciation in blood, milk and cheese. Animal $2: 1610-1618$

Pophaly, S. D., Poonam, P. Singh, H. Kumar, S. K. Tomar, and R. Singh. 2014. Selenium enrichment of lactic acid bacteria and bifidobacteria: A functional food perspective. Trends Food Sci. Technol. 39:135-145.

Rayman, M. P. 2000. The importance of selenium to human health. Lancet 356:233-241.

Robert, T. M. 1992. Pages 299-303 in Standard Methods for the Examination of Dairy Products. 16th ed. Am. Public Health Assoc., Washington, DC.

Schrauzer, G. N. 2003. The nutritional significance, metabolism and toxicology of selenomethionine. Adv. Food Nutr. Res. 47:73-112.

Shaheen, S. O., C. M. Rutterford, S. J. Lewis, S. M. Ring, J. W. Holloway, J. Golding, and A. J. Henderson. 2015. Maternal selenium status in pregnancy, offspring glutathione peroxidase 4 genotype, and childhood asthma. J. Allergy Clin. Immunol. 135:1083-1085.

Sheehan, J. J., and T. P. Guinee. 2004. Effect of pH and calcium level on the biochemical, textural and functional properties of reducedfat Mozzarella cheese. Int. Dairy J. 14:161-172.

Speckmann, B., and T. Grune. 2015. Epigenetic effects of selenium and their implications for health. Epigenetics 10:179-190.

Wadhwani, R., W. R. McManus, and D. J. McMahon. 2011. Improvement in melting and baking properties of low-fat Mozzarella cheese. J. Dairy Sci. 94:1713-1723.

Yang, J., K. H. Huang, S. Y. Qin, X. S. Wu, Z. P. Zhao, and F. Chen. 2009. Antibacterial action of selenium-enriched probiotics against pathogenic Escherichia coli. Dig. Dis. Sci. 54:246-254.

Yasin, M., A. F. El Mehdawi, C. E. Jahn, A. Anwar, M. F. S. Turner, M. Faisal, and E. A. H. Pilon-Smits. 2015. Seleniferous soils as a source for production of selenium-enriched foods and potential of bacteria to enhance plant selenium uptake. Plant Soil 386:385-394. 